\title{
The potential of SLM technology for processing magnesium alloys in aerospace industry
}

\author{
T. Kurzynowski ${ }^{1}$ (D) A. Pawlak ${ }^{1}[1] \cdot$ I. Smolina $^{1}$ (]
}

Received: 27 January 2020 / Revised: 27 January 2020 / Accepted: 11 February 2020 / Published online: 24 February 2020

(c) The Author(s) 2020

\begin{abstract}
Selective Laser Melting (SLM) of magnesium alloys is the technology undergoing dynamic development in many research centres. The results are promising and make it possible to manufacture defect-free material with better properties than those offered by the manufacturing technologies used to date. This review aims to evaluate present state as well as main challenges of using Laser Powder Bed Fusion (L-PBF) for processing magnesium alloys as an alternative way to conventional technologies to manufacture parts in the aerospace industry. This literature review is the first one to outline information concerning the potential to use magnesium alloys in the aerospace industry as well as to summarise the results of magnesium alloy processing using AM technologies, in particular L-PBF. The available literature was reviewed to gather information about: the use of magnesium alloys in the aerospace industry—the benefits and limitations of using magnesium and its alloys, examples of applications using new processing methods to manufacture aerospace parts, the benefits and potential of using L-PBF to process metallic materials, examples of the use of L-PBF to manufacture aerospace parts, and state-of-the-art research into L-PBF processing of magnesium and magnesium alloys.
\end{abstract}

Keywords Magnesium alloys $\cdot$ Additive manufacturing $\cdot$ Laser Powder Bed Fusion (L-PBF) · Aerospace

\section{Introduction}

Over $80 \%$ of all innovations in the aerospace industry owe their existence to the use of new materials and new technologies [1]. Additive manufacturing (AM) technologies that are used to manufacture parts of both plastics and metals are one example of the technologies that have been developed since the 1980s. Presently, AM technologies are increasingly applied for the manufacture of ready-made parts both as indirect [2] and direct [3] technologies. Despite the significant progress that has been made in the field and a wide

A. Pawlak

andrzej.p.pawlak@pwr.edu.pl

T. Kurzynowski

tomasz.kurzynowski@pwr.edu.pl

I. Smolina

iryna.smolina@pwr.edu.pl

1 Faculty of Mechanical Engineering/Centre of Advanced Manufacturing Technologies - Fraunhofer Project Center (CAMT-FPC), Wrocław University of Science and Technology, Wroclaw, Poland range of potential applications, they are not commonly used in the industry.

Aviation is a substantial industry and one of the key transport modes these days. It is then of crucial importance to reduce fuel consumption for reasons of economy and to decrease combustion product emission due to environmental concerns. New alternative fuels, as well as improved engines and aerodynamic components, are one way to achieve these goals. However, weight reduction is the easiest and most cost-effective option that necessities the search for new, lighter, and high-strength construction materials and new manufacturing technologies [4]. Plastics, composites, and light metallic alloys are materials that meet these requirements.

Magnesium and magnesium alloys are one of the lightest metallic materials. Their low density of $1.73 \mathrm{~g} / \mathrm{cm}^{3}$ and the resulting high specific strength make them a perfect alternative to slightly heavier aluminium alloys. The use of light alloys in aviation will result in reduced aircraft weight, which in turn means reduced fuel consumption as well as combustion product emission to the atmosphere. As early as in the 1940s and 1950s, researchers saw the advantages of using magnesium alloys in aviation and identified new 
application fields [5, 6]. Certain limitations and differences between the use of magnesium materials and the then commonly used aluminium alloys were also considered at that time [7]. One of the recent findings in this field is that compared to aluminium alloy 2017A, the AZ31 magnesium alloy is more resistant to low-cycle fatigue as well as high-cycle fatigue at stresses lower than $150 \mathrm{MPa}$ [8]. Since the densities of magnesium alloys and plastics are similar, $\mathrm{Mg}$ alloys also take the place of plastics to ensure higher stiffness [9].

Magnesium alloys are not developing dynamically, mainly due to the processing difficulties which result from magnesium being highly oxidisable and hardly susceptible to plastic cold forming due to its compact hexagonal crystallographic structure. Alloys doped with rare earth elements are a promising group of magnesium alloys as they offer better mechanical properties, also at elevated temperatures, and better corrosion resistance [10]. Similar to other materials, the properties of magnesium alloys can be modified by heat treatment, grain size reduction, production of composites, or surface layer modification [9, 11]. Purging a molten metal with inert gases (Ar, SF6) in the casting process alone reduces the number of contaminants in the material and increases material elongation from 4 to 7\% [12]. An additional problem in the processing of magnesium alloys is the risk of ignition and difficult extinguishing both at elevated temperature and when the material is loose; for example, it has the form of powder or chips [13]. Due to safety reasons caused by the risk of ignition, the use of magnesium alloys in cabin structure was prohibited [14]. That is why a more extensive use of magnesium alloys in the aerospace industry is hindered, in contrast to the automotive or electronic industry.

The purpose of this review was to map the current state of research aimed at implementing L-PBF in the aerospace industry to manufacture parts from magnesium alloys. Such review is necessary considering aerospace industry's growing interest in light alloys, including magnesium alloys, the use of new technologies to improve magnesium alloy performance, considerable progress in the development of AM technologies, and studies that confirmed the suitability of magnesium alloys to be processed by L-PBF.

\section{The use of magnesium alloys in the aerospace industry}

Significant progress in the use of magnesium alloys in the developing aerospace industry was observed as early as in the 1940s [5]. Over the last decade, i.e. since the Society of Automotive Engineers (SAE International) imposed a ban on magnesium alloy used in aircraft seat construction, Federal Aviation Administration (FAA) and SAE International have been working to develop safety standards that would allow the use of magnesium alloys in components of the passenger cabin interior [15] (Fig. 1). Flammability tests conducted in line with the FAA guidelines [16] for a seat assembly consisting of five components made of magnesium alloys showed that the alloys used did not reduce passenger safety [17]. In their latest AS8049C performance standard published in 2015, SAE International changed the provision that banned the use of magnesium alloys in aircraft seat components and now allows the use of magnesium allows provided that FAA standards are met [18].

Several alloying elements and their effect on magnesium ignition were analysed to evaluate the ignition and flammability risks of magnesium alloys [19]. The studies showed that commercial magnesium alloys modified with rare earth elements $\mathrm{Mg}$ - $\mathrm{x}-\mathrm{RE}$ have a higher ignition temperature (780-940 ${ }^{\circ} \mathrm{C}$ ).

Wojtas et al. [20] reported fatigue testing results of AZ31B lever forging designed for the ILX-27 helicopter designed by the Institute of Aviation (Poland). They successfully substituted the element designed to eventually be made of an aluminium alloy with a lighter magnesium alloy and maintained sufficient strength properties in a $100-\mathrm{h}$ simulated flight test. Despite the inferior mechanical properties of magnesium alloy in comparison with the eventual aluminium alloy, magnesium alloy is a good substitute for PA7 aluminium alloy to aid in the helicopter weight reduction.

Many flat and ribbed aerospace parts are manufactured from magnesium alloys by casting and machining [21, 22].

Public units also financially support research programs into the use of magnesium alloys in aerospace. The Sixth Framework Programme (FP6) of the European Commission made it possible to complete two large projects with such major players as EADS Deutschland GmbH (Germany),

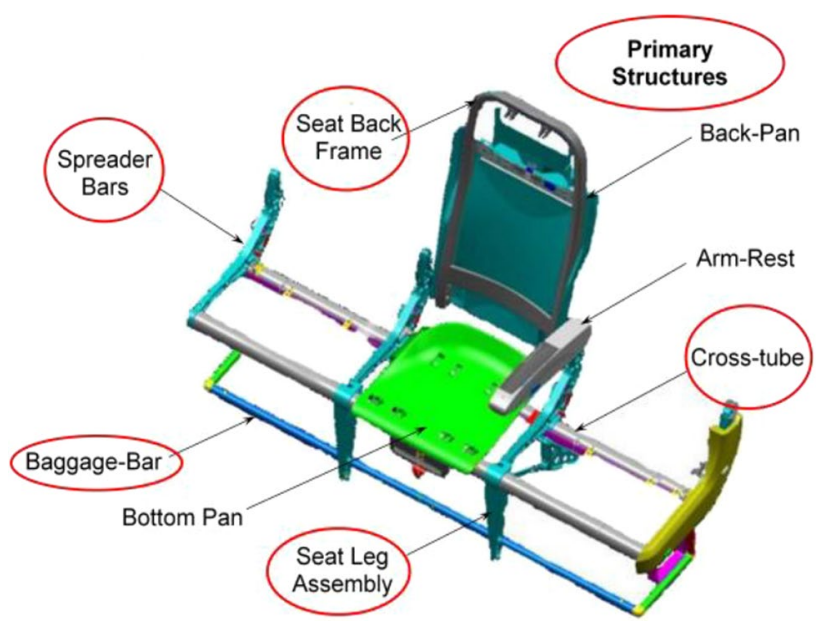

Fig. 1 Schematic of major structural seat components, Reprinted from The Application of Magnesium Alloys in Aircraft InteriorsChanging the Rules, by Davis [15]. Reprinted with permission 
Airbus (HQ in the Netherlands), Eurocopter (now-Airbus Helicopters SAS, HQ in France), Israel Aviation Industry (Israel), Liebherr-Aerospace SAS (France), and Alenia (Italy).

New and modified magnesium products with material properties higher than those of the existing aluminium alloys were developed as a result of these projects [23]. It was possible due to the advances in the magnesium materials forging technology and surface modification that improved corrosion resistance up to 60 times. The new forging processes reduced the costs of manufacturing secondary fuselage components (e.g. window frames, panels of internal inspection doors), and the mechanical requirements for aluminium products were met [24] (Figs. 2 and 3).

\section{New achievements in the processing of magnesium alloys}

New technological processes are being developed to promote the use of magnesium alloys in the industry, take advantage of their indisputable potential, and improve characteristics that remain unsatisfactory. Low-strength properties of magnesium alloys when compared to $\mathrm{Al}$ and $\mathrm{Ti}$ alloys (especially at elevated temperatures) and low corrosion resistance are the main factors limiting the use of these materials in the industry. One of the ways to improve the strength properties is microstructure refinement which results in superplasticity in certain alloys ( $\mathrm{Mg}-\mathrm{Al}-\mathrm{Zn}, \mathrm{Mg}-\mathrm{Zn}-\mathrm{Zr}$, and $\mathrm{Mg}-\mathrm{Li})$. The superplastic effect allows freedom to create complex shapes and makes it possible to produce near net shape structures. It

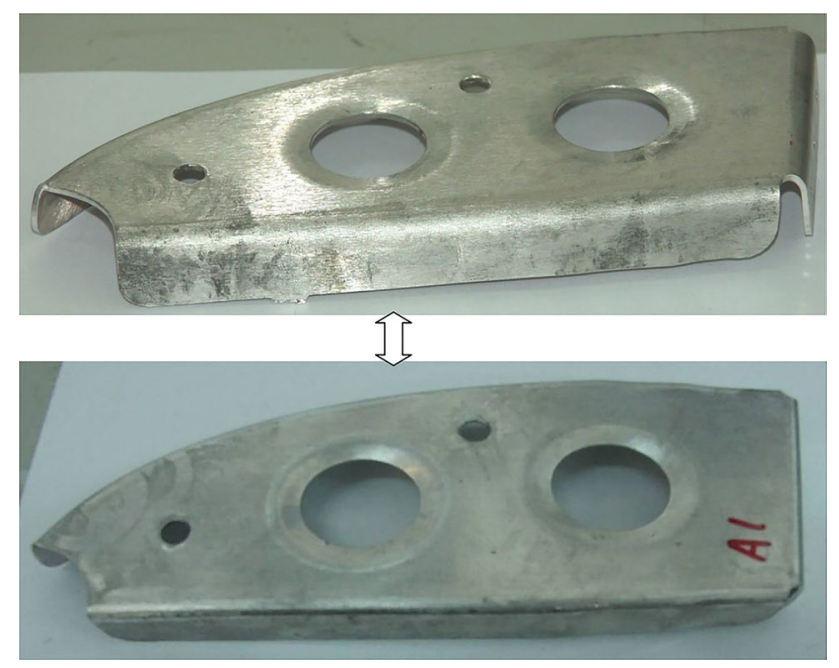

Fig. 2 "Comparison between success pad forming of ZE10A-F (up) and original Al part (down)", Reprinted from MAGFORMING Development of new Magnesium Forming Technologies for the Aeronautics Industry, by Henn and Fein [24], Copyright 2010 by MagForming Consortium. Reprinted with permission

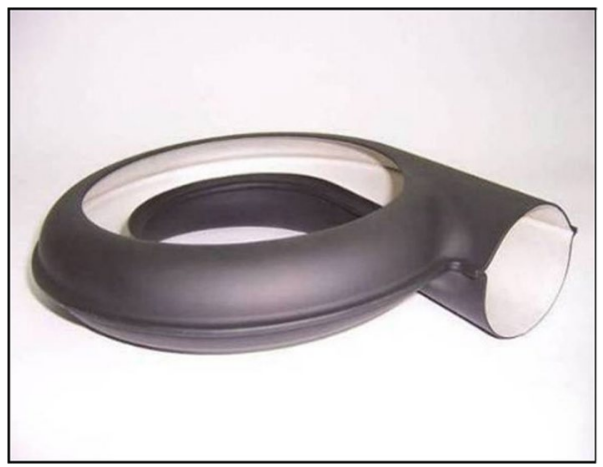

Fig. 3 "Compressor scroll. The final shape produced by PALBAMAMTS", Reprinted from MAGFORMING Development of new Magnesium Forming Technologies for the Aeronautics Industry, by Henn and Fein [24], Copyright 2010 by MagForming Consortium. Reprinted with permission

also improves mechanical properties [25]. Therefore, several authors have reported using various methods to obtain a finegrained microstructure.

Fine-grained magnesium alloy microstructure can be achieved using traditional thermo-mechanical treatment (rolling, extrusion) [26] and equal-channel angular pressing (ECAP) [27]. The three-slide forging press process made it possible to manufacture rib elements with complex geometries, save on material costs, and improve the mechanical properties of the products [21, 28, 29].

Another process which significantly reduced the grain size was machining with simultaneous cooling of the treated surface with liquid nitrogen [30]. However, there is a risk that fine chips that are formed during machining may ignite [13]. Grain refinement in magnesium alloy after ECAP process resulted in better mechanical strength, whereas machining improved the hardness of the near-to-surface layer almost two times. A similar surface effect is observed when laser surface treatment is used [11, 31, 32]. Grains can also be refined during the casting process itself, using $15 \mathrm{~Hz}$ frequency ultrasounds to generate vibrations in the solidifying metal [33].

High current pulsed electron beam (HCPEB) surface treatment [34] may increase wear resistance up to sevenfold. A similar effect is observed upon applying a coating by atmospheric plasma spraying (APS) [35].

Alloying and formation of composites are the evident methods that can be used to improve the properties of materials. A small addition of beryllium (a few parts per million) improved AZ91 alloy's corrosion resistance at elevated temperature [36] (Fig. 4). The addition of zinc-containing icosahedral quasicrystalline phase increased hardness by up to $500 \%$ after additional heat treatment [37] at the cost of higher brittleness of the material. Wang et al. [38] avoided the formation of the quasicrystalline phase by introducing 


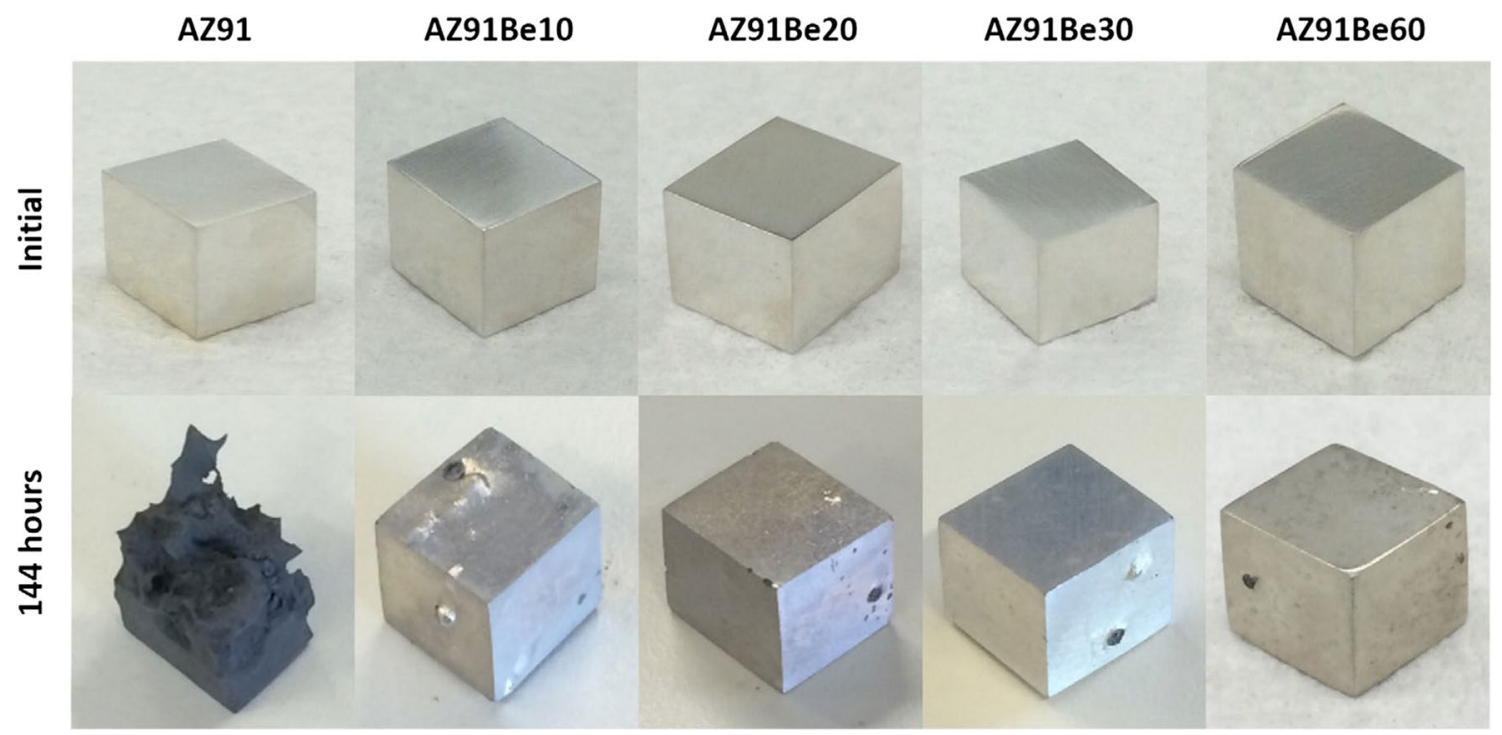

Fig. 4 Macroscopic images of AZ91 and the AZ91Be magnesium alloys after 144-h oxidation at $400{ }^{\circ} \mathrm{C}$, Reprinted from Oxidation resistance of Mg-9Al-1Zn alloys micro-alloyed with Be, by Tan et al. [36], Copyright by 2015 Elsevier B.V. Reprinted with permission

zinc and yttrium into AM50 alloy, which maintained the original properties of the material.

Strengthening of AZ31 alloy with SiC nanoparticles and carbon nanotubes in the friction stir welding process helped to refine its microstructure and increase the yield strength at the cost of tensile and elongation strength [39]. Better results, which increase the tensile strength, may be achieved when the alloy is reinforced by carbon fibre [40]. The addition of boron carbides to AZ91D alloy increases hardness and wear resistance [41]. It was also found that the addition of 50\% graphite flakes to pure magnesium increases the thermal conductivity of the material so that it is four times higher than the conductivity of copper [42].

A detailed list of technological processes used to modify the microstructure and properties of magnesium alloys is shown in Table 1.

\section{L-PBF technology}

Laser Powder Bed Fusion (L-PBF or SLM/DMLS-Selective Laser Melting/Direct Metal Laser Sintering) is one of many additive manufacturing technologies. It represents the powder bed fusion (PBF) group that encompasses many other technologies. Apart from L-PBF, it includes SLS/ SHS (Selective Laser Sintering/Selective Heat Sintering) and EBM (Electron Beam Melting). All of the technologies mentioned above share the principle of operation, that is, the powder bed is melted as a result of interaction with the source of energy: either a laser beam (L-PBF/SLM/DMLS, SLS) or an electron beam (EBM) [43] (Fig. 5). The significant difference between the technologies that employ laser is its power which determines the results of the technological process, i.e. either sintering (SLS) or complete melting of the powder material (L-PBF).

Additive manufacturing using powder offers several advantages over other technologies (e.g. wire feed) which include better tolerances, better surface finish quality, and a possibility to create geometrically complex shapes [44].

The process of manufacturing parts using Selective Laser Melting consists of heating and melting the powder with a laser beam, followed by rapid cooling and solidification of the melted metal. High-temperature gradient and high cooling rate generate textured microstructures of metal alloys, the majority of which are characterised by columnar grains built of oriented packages of dendrite cells, very fine grains, cellular and interdendritic microsegregation, and occurrence of non-equilibrium phases as well as solution strengthening resulting from supersaturation [45]. However, the solidification conditions of a liquid metal cause negative phenomena, inducing residual stresses [46] and defects taking the form of pores and various cracks. Laser type and the selection of variable parameters have a decisive impact on the quality of the manufactured parts [47]. Over 100 process parameters control L-PBF technology process. Many of them are fixed depending on machine type, used powder, or is set for the entire process, like these concerning process atmospheres, or energy source, but there are also adjustable parameters, in which proper value selections could tune the process to obtain demanded results. For example, the widely used high-power continuous-wave $(\mathrm{CW})$ lasers and parallel long-pulsed lasers (nanosecond to millisecond pulse) are characterised, as opposed to femtosecond 
Table 1 A list of technological processes used to improve the properties of magnesium alloys

\begin{tabular}{|c|c|c|c|}
\hline Process & Material & Result & Change of properties \\
\hline $\begin{array}{l}\text { Adding graphite in spark plasma sinter- } \\
\text { ing [42] }\end{array}$ & $\begin{array}{l}\mathrm{Mg}, \mathrm{AZ} 61 \\
\mathrm{AZ} 31, \mathrm{Mg}- \\
0.9 \mathrm{Ca}\end{array}$ & $\begin{array}{l}\text { Graphite flakes ( } 50 \text { vol. } \% \text { ) uniformly } \\
\text { distributed in alloy base }\end{array}$ & Increased thermal conductivity \\
\hline $\begin{array}{l}\text { Machining with liquid nitrogen cooling } \\
\text { [30] }\end{array}$ & AZ31 & $\begin{array}{l}\text { Grains refined from the original } 12 \mu \mathrm{m} \\
\text { to } 31 \mathrm{~nm}\end{array}$ & $\begin{array}{l}\text { Near-to-surface layer hardness increased } \\
\text { by } 87 \%\end{array}$ \\
\hline Coating [35] & AZ31 & $\begin{array}{l}\text { Adding a composite coating: } \mathrm{Al}_{2} \mathrm{O}_{3}-13 \% \\
\text { wt. TiO- }{ }_{2} \text { and } \mathrm{Al}_{2} \mathrm{O}_{3}-40 \% \text { wt. } \mathrm{TiO}_{2}\end{array}$ & $\begin{array}{l}\text { Increase in near-to surface layer hardness } \\
\text { to } 1500 \mathrm{HVO} .1 \text { and } 800 \mathrm{HV} 0.1\end{array}$ \\
\hline $\begin{array}{l}\text { Adding } \mathrm{SiC} \text { nanoparticles and carbon } \\
\text { nanotubes in friction stir welding [39] }\end{array}$ & AZ31 & $\begin{array}{l}\text { Microstructure refinement, homogeni- } \\
\text { sation of microstructure, and lower } \\
\text { microhardness dispersion }\end{array}$ & $\begin{array}{l}\text { Increased yield strength, decreased ten- } \\
\text { sile, and elongation strength }\end{array}$ \\
\hline $\begin{array}{l}\text { Equal-channel angular pressing (ECAP) } \\
\text { [27] }\end{array}$ & AZ61 & Grains refined by $85 \%$ & Mechanical strength increased by $24 \%$ \\
\hline Casting with ultrasonic vibration [33] & AZ91 & Grains refined by $50 \%$ & $\begin{array}{l}\text { Tensile and yield strength increased by } \\
20 \% \text {, hardness increased by } 30 \%\end{array}$ \\
\hline $\begin{array}{l}\text { High current pulsed electron beam } \\
\text { (HCPEB) [34] }\end{array}$ & AZ91 & $\begin{array}{l}\text { Evaporation of } \mathrm{Mg} \text { and dissolution of } \\
\mathrm{Mg}_{17} \mathrm{Al}_{12} \text { phase in the surface layer }\end{array}$ & $\begin{array}{l}\text { Microhardness increased by } 125 \% \text { and } \\
\text { wear rate reduced by } 85 \%\end{array}$ \\
\hline Micro-alloying with beryllium [36] & AZ91 & $\begin{array}{l}\text { Delayed oxygen diffusion and } \mathrm{Mg} \text { ions } \\
\text { evaporation }\end{array}$ & Improved oxidation resistance \\
\hline Laser surface treatment [31] & AZ91D & Dissolution of $\beta$ phase & $\beta$ Phase hardness increased by $15 \%$ \\
\hline $\begin{array}{l}\text { Adding } \mathrm{B}_{4} \mathrm{C} \text { and graphite in stir casting } \\
\text { [41] }\end{array}$ & AZ91D & $\begin{array}{l}\text { Dispersed } \mathrm{B}_{4} \mathrm{C} \text { and graphite particles } \\
\text { uniformly distributed in alloy base }\end{array}$ & $\begin{array}{l}\text { Increased material hardness, tensile } \\
\text { strength, and wear }\end{array}$ \\
\hline $\begin{array}{l}\text { Adding carbon fibre in liquid-solid } \\
\text { extrusion [40] }\end{array}$ & AZ91D & $\begin{array}{l}\text { Continuous graphite fibres }(\varnothing 7 \mu \mathrm{m}) \\
\text { uniformly distributed in alloy base }\end{array}$ & Tensile strength increased by $81 \%$ \\
\hline Alloying with zinc [37] & WE43 & $\begin{array}{l}\text { Introduction of icosahedral quasicrystal- } \\
\text { line phase (I-phase) }\end{array}$ & $\begin{array}{l}\text { Hardness increased by } 50 \% \text { and } 500 \% \\
\text { after ageing }\end{array}$ \\
\hline Extrusion using KOBO method [26] & WE43 & $\begin{array}{l}\text { Grains refined from the original } 10.7 \mu \mathrm{m} \\
\text { to } 0.9 \mu \mathrm{m}\end{array}$ & Hardness increased by $30 \%$ \\
\hline Laser surface alloying [11] & $\mathrm{Mg}+\mathrm{A} 1 \mathrm{Si} 20$ & $\begin{array}{l}\text { Microstructure refinement of the near-to- } \\
\text { surface layer enriched with } \mathrm{Al} \text { and } \mathrm{Si}\end{array}$ & Sevenfold increase in hardness \\
\hline Alloying with zinc and yttrium [38] & AM50 & $\begin{array}{l}\text { Microstructure refinement without the } \\
\text { formation of I-icosahedral quasic- } \\
\text { rystalline phase }\left(\mathrm{Mg}_{3} \mathrm{Zn}_{6} \mathrm{Y}\right) \text {. Higher } \\
\text { content of } \beta \text { phase }\end{array}$ & $\begin{array}{l}\text { Increased } R_{\mathrm{m}}(206.63 \mathrm{MPa}), R_{\mathrm{p} 0.2} \\
(92.5 \mathrm{MPa}) \text { and elongation (up to } \\
10.04 \%)\end{array}$ \\
\hline
\end{tabular}

fibre lasers, by lower precision in the manufacture of parts and use of limited groups of metal alloys-due to a wide heat-affected zone in the case of metals with high or low melting point and/or high conductivity [48]. Another factor which also affects the results of manufactured parts is build strategy, which includes not only the built orientation and position inside the process chamber but also the scanning strategy for each deposited powder layer [49]. Rashid et al. [50] combined the observations as mentioned above and proposed the new term- "energy per layer", which includes the total area of melted powder on each layer, that affects the resulted microstructure and porosity and could describe and control process results.

There are several physical phenomena during the L-PBF process that are the key factors determining the quality of the manufactured parts. These include metal powder absorptivity concerning the laser radiation, balling effect causing discontinuities in the melted metal, and thermal fluctuations that frequently result in cracking and hence in the destruction of the component being manufactured [51, 52].

L-PBF is the most frequently used powder bed technique within additive manufacturing for processing aerospace components. In terms of manufacturing organisation and costs, using additive manufacturing, and in particular L-PBF, has two main advantages [53]: (1) small batch production does not increase production costs in contrast to casting technologies, and (2) complex product shape also does not increase production costs in contrast to conventional (subtractive) technologies.

The most important disadvantages of the parts manufactured using powder bed fusion processes include a potential lack of melting between the layers and porosity [54]. Some authors $[54,55]$ stated that the porosity of over $6 \%$ significantly affects the mechanical properties of the metallic materials being manufactured.

The AM technologies outlined above offer the possibility to efficiently use alloying elements and hence obtain 


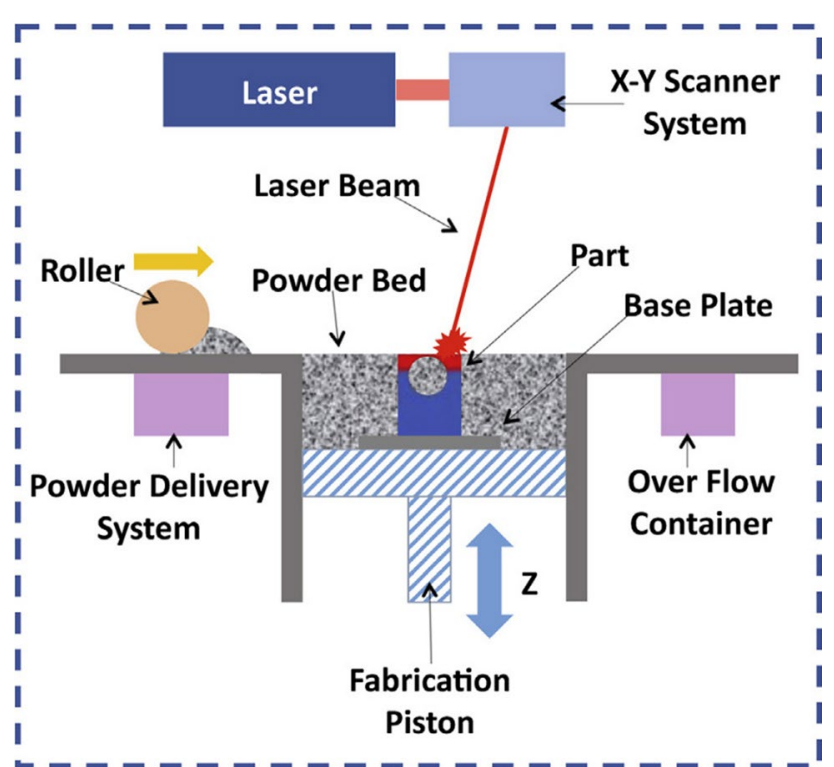

Fig. 5 Diagram of an SLM machine, Reprinted from An overview of Direct Laser Deposition for additive manufacturing; Part I: Transport phenomena, modelling and diagnostics, by Thompson et al. [43], Copyright by 2015 Elsevier B.V.Reprinted with permission

new alloys with better mechanical and thermal properties, and/or with increased resistance to abrasive and corrosive wear [56]. Moreover, the features of the process such as layer by layer and selective melting of the powder material enable manufacturing of parts with complex shapes and any designed (solid or having the designed porosity) internal geometry [57]. These advantages of AM technologies, and in particular of L-PBF, make them increasingly popular in the industry. They have gained immense recognition and are most widely used in medical and aerospace industries which are marked by high demand for custommade products whose final properties can be tailored to the specific requirements.

\section{The use of L-PBF technology in the aerospace industry}

Examples of aerospace parts manufactured by L-PBF are shown in Fig. 6. They include a fuel nozzle made of cobalt alloy [58], borescope made of nickel-based alloy-Inconel 718 [59] and various latches and supports made of titanium alloys. Titanium alloys, e.g. Ti6Al4 V, are well recognised and frequently substitute steel as their use reduces the buy-to-fly ratio from 15 to 1 [54].

The benefits of using L-PBF in the aerospace industry are as follows [60]:
1. It is possible to develop and manufacture a new geometry of the external and internal part, e.g. internal cooling ducts [44], which is impossible in the case of conventional technologies;

2. Energy efficiency and considerable reduction in time, material, waste, and other costs associated with the manufacture of a new part;

3. Less negative environmental impact;

4. Shorter time to market.

Topological optimisation is used to take advantage of the main benefits of L-PBF in the aerospace industry, which include reduced weight and amount of material needed to manufacture a specific part. Bamberg et al. [59] reported an example of such optimisation carried out for an aerospace part made of aluminium alloy which is subject to three-point bending (Fig. 6.3-6.5) [59, 61]. However, limitations of L-PBF technology should be taken into account, especially brittle fracture behaviour for material without any heat treatment [62].

To conclude, AM technologies are currently used in the aerospace industry to produce non-critical parts with complex geometries or for which lighter alloys of satisfactory strength can be used to significantly reduce weight and ensure topological optimisation of their inner shape. Examples of parts produced by L-PBF or EBM that were implemented or partially implemented are listed in Table 2 .

However, there are still many challenges to address before AM technologies, in particular L-PBF, can be fully implemented in the aerospace industry.

1. The main challenge is to ensure stability and repeatability of the process to eliminate internal defects, surface roughness, and achieve high geometry tolerance [44].

2. Post-processing requirement. It was assumed that each part produced with the AM technology requires postprocessing to reduce (a) porosity with the use of hot isostatic pressing (HIP) and/or (b) surface roughness [71] by surface machining.

3. Certification and standardisation $[65,72]$. Lack of methods for verifying the parts produced with AM technologies or standards regarding the terminology, file format, or processing procedures for various alloys significantly hinders the implementation of AM technologies.

\section{The use of L-PBF technology for magnesium processing}

The first attempts to melt magnesium-based materials and produce spatial specimens by L-PBF were reported in 2012 [73]. It was the first report that discussed difficulties 


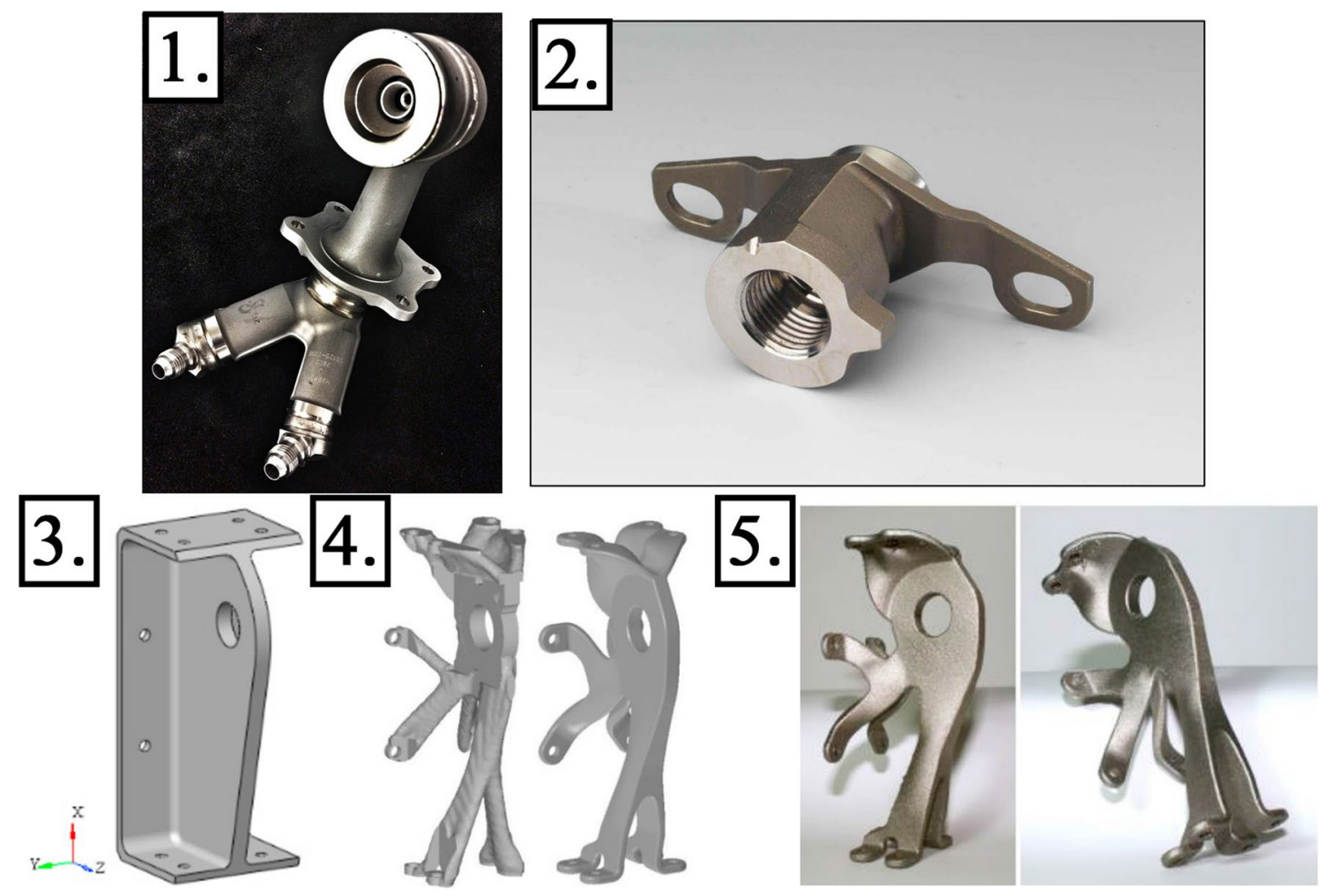

Fig. 6 Examples of aerospace parts manufactured by SLM technology. (1) "A 3D printed fuel nozzle made by General Electric Company", Reprinted from Additive manufacturing at GE Aviation, 2014, GE Reports, Copyright by 2014 General Electric. (2) "Additive manufactured boroscope boss", Reprinted from In-Process Control of Selective Laser Melting by Quantitative Optical Tomography by J. Bamberg, et al., 2016, 19th World Conference on Non-Destructive Testing 2016, Copyright by 2016 Creative Commons. (3) "Original

in processing $\mathrm{Mg}-9 \% \mathrm{Al}$ alloy with a laser beam and observed evaporation of magnesium during the process.

A year later, L-PBF was used to produce spatial specimens from AZ91 alloy with almost zero porosity [74]. Gieseke et al. [75] reported similar results for pure magnesium and $\mathrm{MgCa} 0.8$ alloy. In this paper, the authors described the evaporation of magnesium (Fig. 7) and pointed out that scanning direction affects the resulting specimen surface quality. They suggested that the scanning direction is changed for successive layers considering the good quality of the side surface of specimens, perpendicular to the scanning direction.

The main aim of the study [74] discussed above was to explore the potential of magnesium alloys as a bioresorbable implant material. Other authors discussed the problem of low corrosion resistance of magnesium alloys and reported successful attempts to increase it [76]. In 2015, the options to manufacture scaffolds from WE43 and AZ91 alloys by L-PBF were presented [77] (Fig. 8). component", (4) "Topological optimised (TO) solution (left) and optimised component final design (right)", (5) "Optimised component manufactured", Reprinted from Selective Laser Melting (SLM) and topology optimisation for lighter aerospace components by M. Seabra et al., 2016, Procedia Structural Integrity, PROSTR (Procedia Structural Integrity) Hosting by Elsevier Ltd. Copyright by 2016 Elsevier B.V. Reprinted with permission

Additionally, Gieseke's team collaborated with Magnesium Elektron (England) to determine the optimum L-PBF technology parameters for processing Elektron ${ }^{\circledR} 43$ alloy [78-80]. The authors reported a considerably reduced porosity in the produced specimens as a result of double scanning of a layer and simultaneous addition of the material between successive scanning passes of the layer. According to the authors, residual porosity was the result of a disturbed flow of the shielding gas that transferred contaminants from magnesium vapour onto the melted layers. Other authors [81] established that such contaminants deposited on the powder surface in the form of oxide layers might result in weak interlayer bonding.

Due to the oxidation and balling phenomena that accompany L-PBF, Scanning Time Interval (STI) parameter was analysed, which denotes time delay in the process that occurs between the completion of a layer scanning and further application and melting of the next layer [82]. When the time delay between scanning the next layers is of appropriate 
Table 2 A list of aerospace parts produced using additive manufacturing technologies [44, 58, 59, 63-70]

\begin{tabular}{|c|c|c|c|}
\hline Part & Material/technology & Company & Characteristics/comments \\
\hline $\begin{array}{l}\text { Engine chamber for the SuperDraco } \\
\text { launch escape system }\end{array}$ & Inconel/L-PBF & SpaceX & $\begin{array}{l}3 \text { months from concept to the first hot } \\
\text { fire }\end{array}$ \\
\hline Satellite propellant tank & Titanium/EBAM ${ }^{\circledR}$ & Lockheed Martin Space Systems & $\begin{array}{l}\text { Product cost reduced by 55\%; TTM } \\
\text { reduced by } 80 \% \text { using EBAM }\end{array}$ \\
\hline $\begin{array}{l}\text { Waveguide brackets on Juno space- } \\
\text { craft }\end{array}$ & Titanium/EBM & Lockheed Martin & Reduced lead time and cost \\
\hline Leap engine nozzle & $\mathrm{CoCr} / \mathrm{L}-\mathrm{PBF}$ & General Electric (GE) & $\begin{array}{l}\text { One piece instead of an assembly of } \\
20 \text { parts; } \\
\text { Reduced weight }\end{array}$ \\
\hline Turbine blades & Inconel 718/L-PBF or EBM & General Electric (GE) & $\begin{array}{l}\text { Multimaterial blades optimised for } \\
\text { (a) strength and (b) heat resistance }\end{array}$ \\
\hline $\begin{array}{l}\text { Borescope bosses for A320neo } \\
\text { Geared Turbofan }\end{array}$ & Inconel 718/L-PBF & MTU Aero Engines & $\begin{array}{l}\text { Tool-free manufacturing and lower } \\
\text { material consumption }\end{array}$ \\
\hline Cabin bracket for the A350 XWB & Titanium/EBM & Airbus & $\begin{array}{l}\text { The bionic component weighs } 30 \% \\
\text { less than the traditionally milled } \\
\text { piece }\end{array}$ \\
\hline $\begin{array}{l}\text { Nacelle hinge bracket on Airbus } \\
\text { A320 }\end{array}$ & Titanium/L-PBF & EOS & $\begin{array}{l}\text { Saves } 10 \mathrm{~kg} \text { per shipset } \\
\text { Ti was used instead of steel }\end{array}$ \\
\hline Buckle & Titanium/metal 3D printing & Airbus & $\begin{array}{l}\text { Ti was used instead of steel } \\
\text { The new ergonomic optimised design } \\
55 \% \text { reduction in weight for one } \\
\text { buckle }\end{array}$ \\
\hline Eurostar E3000 satellite & Aluminium/metal 3D printing & Airbus & $\begin{array}{l}\text { Less weight (up to } 35 \% \text { ) and better } \\
\text { stiffness (up to } 40 \% \text { ) compared to } \\
\text { traditional manufacturing; } \\
\text { A single piece replaced an assembly of } \\
\text { several aluminium components and } \\
\text { up to } 44 \text { rivets }\end{array}$ \\
\hline
\end{tabular}

Fig. 7 Evaporation products formed during SLM processing of magnesium alloys. "Selective Laser Melting of magnesium", Reprinted from Selective Laser Melting of Magnesium Alloys for Manufacturing Individual Implants by Gieseke et al. [75], Copyright by 2014 DDMC, Reprinted with permission

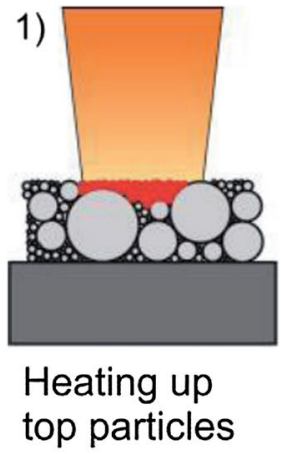

(c) $\mathrm{LZH}$

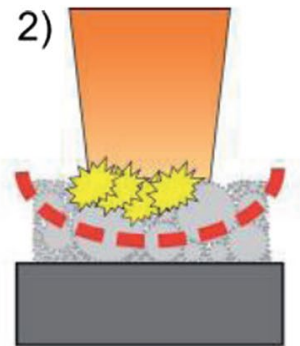

\section{Vaporizing} top particles and inducing a shock wave

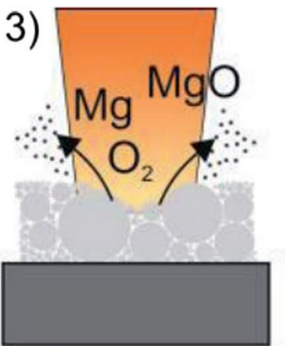

Releasing nanosize particles

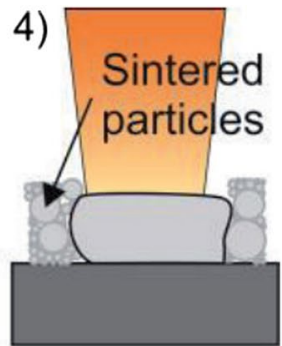

Track formation and reoxidation

length, the produced specimen cools down partially, which results in better wettability and oxidation resistance of the material. This also improves the surface quality of the produced specimens by reducing the number of partially melted powder particles attached to the specimen's surface.

Pawlak et al. [83, 84] suggested that the design of experiments methods is used to facilitate the optimisation of the L-PBF process for AZ31 alloy. The high relative densities and high hardness of the alloy that exceed the values obtained for wrought material further confirm that

magnesium alloys are suitable for the L-PBF processing. In another study of this researcher on magnesium alloys in L-PBF, a relation between process parameters and obtained results was presented [85]. Authors reported that significant influence on obtained material hardness has Laser Power (LP), which was common observation for L-PBF processing, while for porosity in defined processing window scanning speed has a slightly higher influence than laser power.

Salehi et al. [86] report that magnesium powders strongly react with even residual content of oxygen present 

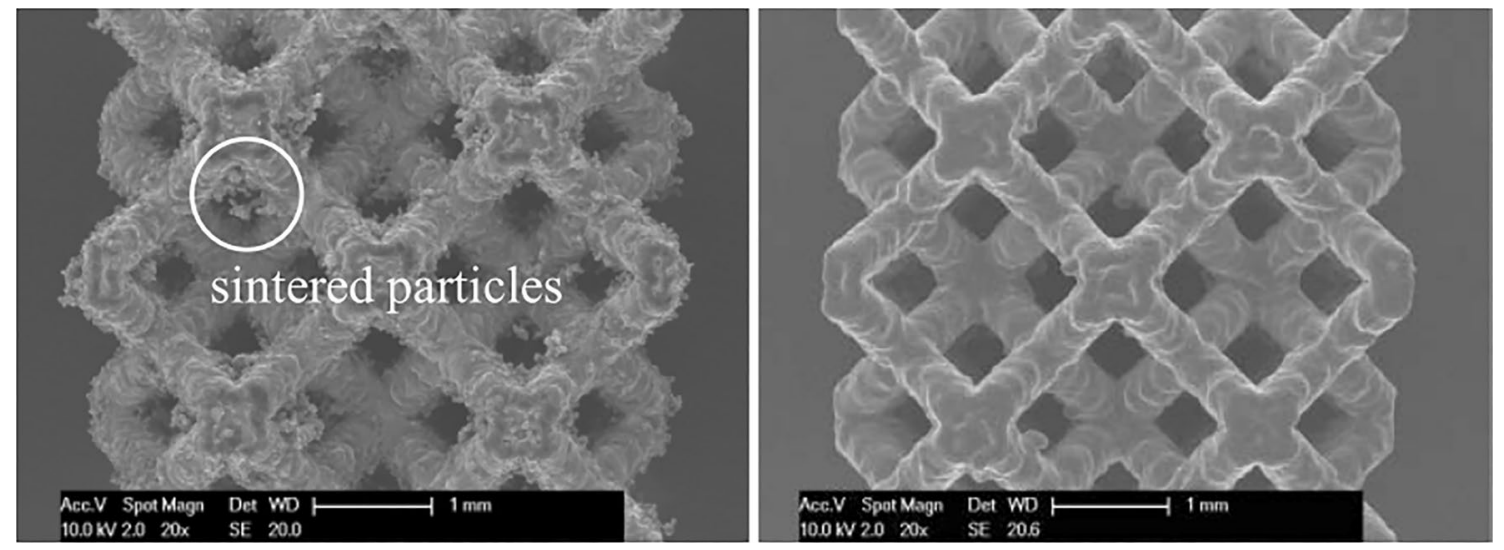

Fig. 8 SEM image of WE43 structure as- processed (left) and after sandblasting (right), Reprinted from Selective Laser Melting of magnesium alloys by Jauer et al. [77], Copyright by 2015 Open Access, Reprinted with permission

in impurities of a protective gas atmosphere. This research is essential for the L-PBF process and points at one more source of difficulties in manufacturing high-quality parts from magnesium in powder bed fusion processes.

A list of different analysed materials and obtained microstructures and mechanical properties is listed in Table 3.

The research focused on microstructure, and chemical composition of magnesium-based powders processed in L-PBF technology reports hard to omit vaporisation, mainly magnesium element $[77,85,87,88]$. Because of rapid cooling rate and high energy input, characteristic microstructure for magnesium alloys processed in L-PBF reveals scan track formation with ultrafine microstructure on track centre and coarser grains but still fine on the boundaries of the formed scan track [85, 89, 90]. Another parameter influence was evaluated by Savalani et al. [91], which points that preheating allows to obtain a flatter and more regular scan track.

The papers discussed above show growing interest in the production of parts from magnesium alloy by L-PBF. Positive results of studies carried to date as well as promising properties of such alloys encourage researchers and manufacturers to explore the new application field and new possibilities it brings. Additive manufacturing of light metallic materials ( $\mathrm{Mg}$ and $\mathrm{Al}$ alloys) that pose processing difficulties will be studied extensively in the near future.

\section{Summary}

Magnesium alloys can be used to manufacture parts for the aerospace industry. The resulting parts are characterised by good specific strength (due to low weight) and fatigue resistance. Modern technologies, e.g. additive manufacturing, may help overcome difficulties encountered when processing magnesium alloys.

The methods of shaping magnesium alloy products used to date such as forging, casting, or equal-channel angular pressing (ECAP) have many limitations, e.g. no freedom in shaping a complex geometry of the product, risk of chip ignition during machining, and ageing process which significantly worsens mechanical properties.

The use of AM technologies, in particular Laser Powder Bed Fusion (L-PBF), to process magnesium alloys will enable the production of parts of the specific shape in a single technological process. First, results of studies into L-PBF processing of magnesium alloys reported by several research centres are promising. The specimens manufactured have three-dimensional geometries without porosity or delamination, which had been the primary challenge of additive processes. However, there remain a few issues to be solved to ensure successful implementation. The researchers need to (a) ensure repeatability, (b) eliminate porosity, and (c) ensure scalability (capability to expand from the production of small to large parts).

Joint Technology Initiative (JTI) set up by the Advisory Council for Aeronautics Research in Europe (ACARE, HQ in Belgium) in the European Union also confirms the strong interest of aerospace industry in AM technologies and magnesium-based light alloys [97]. Seven framework programmes were established as part of this initiative whose aim was to reduce $\mathrm{CO}_{2}$ and NOx emissions and reduce the levels of noise produced by aircraft. As a result of the Clean Sky programme, a few demonstrators were manufactured, e.g. using Electron Beam Melting, which decreased the weight of door hinges by 52\%. The "Shelf Removal Assembly" demonstrator made of WE43 magnesium alloy, which decreased the weight by $20 \%$ compared to the component made of 2024 aluminium alloy, is another example. 
Table 3 Summary of microstructures and mechanical properties for various magnesium powders processed by SLM

\begin{tabular}{|c|c|c|c|c|c|}
\hline References & Material & Microstructure & Hardness & UTS/YS (MPa) & Elongation (\%) \\
\hline $\begin{array}{l}\mathrm{Ng} \text { et al. and Savalani et al. } \\
\text { [91-93] }\end{array}$ & $\mathrm{Mg}$ & $\begin{array}{l}\text { Fine } \alpha \text {-Mg microstructure, } \\
\text { increasing grain size with } \\
\text { an increase in laser energy } \\
\text { density }\end{array}$ & $0.59-0.95 \mathrm{GPa}$ & n.a. & n.a. \\
\hline Hu et al. [82] & $\mathrm{Mg}$ & Fine grained & 44.75-52.43 HV0.05 & n.a. & n.a. \\
\hline Pawlak et al. [84, 85, 94] & AZ31B & $\begin{array}{l}\text { Non-uniform fine } \alpha \text {-Mg } \\
\text { structure (equiaxed and } \\
\text { elongated grains) with } \\
\gamma-\mathrm{Mg}_{17} \mathrm{Al}_{12} \text { eutectic }\end{array}$ & 64-71 HV0.5 & $207-212 / 183-187$ & $7.7-7.9 \%$ \\
\hline Liu et al. [95] & AZ61 & $\begin{array}{l}\text { Equiaxed } \alpha-\mathrm{Mg} \text { grains and } \\
\text { fully divorced eutectic } \\
\mathrm{Mg} 17 \mathrm{Al} 12 \text { distributed } \\
\text { along the grain boundaries }\end{array}$ & n.a. & 239.3-287.1/216.8-233.4 & $2.14-3.28 \%$ \\
\hline Wei et al. [96] & AZ91D & $\begin{array}{l}\text { Equiaxed } \alpha \text {-Mg grains and } \\
\text { fully divorced eutectic } \\
\beta-\mathrm{Mg}_{17} \mathrm{Al}_{12}\end{array}$ & $85-1000.2 \mathrm{HV}$ & $274-296 / 237-254$ & $1.24-3 \%$ \\
\hline Taltavul et al. [31] & AZ91D & $\begin{array}{l}\alpha \text {-Mg matrix with large } \\
\text { grains of } \beta-\mathrm{Mg}_{17} \mathrm{Al}_{12}\end{array}$ & 123-174 HV & n.a. & n.a. \\
\hline Gieseke et al. [78, 79] & WE43 & Fine-grained microstructure & n.a. & $312 / 194$ & $14 \%$ \\
\hline Li et al. [90] & WE43 & $\begin{array}{l}\text { Equiaxed fine grains with } \\
\text { ultrafine elongated grains } \\
\text { on the melt pool bounda- } \\
\text { ries. }\end{array}$ & n.a. & n.a. & n.a. \\
\hline Wei et al. [87]. & ZK60 & $\begin{array}{l}\text { Fine dendritic (refinement } \\
\text { thanks to increased } \mathrm{Zr} \\
\text { content) with } \mathrm{Mg}_{7} \mathrm{Zn}_{3} / \\
\text { MgZn precipitates on grain } \\
\text { boundaries. }\end{array}$ & $78 \pm 10$ HV0.2 & n.a. & n.a. \\
\hline Shuai et al. [88] & ZK60 & $\begin{array}{l}\text { Fine dendritic to columnar } \\
\text { structure with an increase } \\
\text { in volume energy density of } \\
\alpha-\mathrm{Mg}_{\text {with precipitations of }} \\
\beta-\mathrm{Mg}_{7} \mathrm{Zn}_{3}\end{array}$ & 70.1-89.2 HV & n.a. & n.a. \\
\hline Zhang et al. [73] & $\mathrm{Mg}-9 \mathrm{Al}$ & $\begin{array}{l}\text { Equiaxed grains of } \alpha-\mathrm{Mg} \\
\text { with precipitations of } \\
\mathrm{Mg}_{17} \mathrm{Al}_{12}, \mathrm{MgO} \text {, and } \mathrm{Al}_{2} \mathrm{O}_{3} \\
\text { on grain boundaries. }\end{array}$ & 66-85 HV0.025 & n.a. & n.a. \\
\hline Proaño et al. [89] & $\mathrm{Mg}-9 \mathrm{Al}-2 \mathrm{Ca}$ & $\begin{array}{l}\text { Fine-grained scan track } \\
\text { centre and coarser grains at } \\
\text { scan track boundaries. }\end{array}$ & n.a. & $332 / 253$ & $3,2 \%$ \\
\hline
\end{tabular}

Acknowledgements This work is supported by the Polish National Centre for Research and Development within the project "Magnesiumbased alloys processed with Selective Laser Melting technology for aeronautical applications" (No. LIDER/8/0109/L-7/15/NCBR/2016).

Open Access This article is licensed under a Creative Commons Attribution 4.0 International License, which permits use, sharing, adaptation, distribution and reproduction in any medium or format, as long as you give appropriate credit to the original author(s) and the source, provide a link to the Creative Commons licence, and indicate if changes were made. The images or other third party material in this article are included in the article's Creative Commons licence, unless indicated otherwise in a credit line to the material. If material is not included in the article's Creative Commons licence and your intended use is not permitted by statutory regulation or exceeds the permitted use, you will need to obtain permission directly from the copyright holder. To view a copy of this licence, visit http://creativecommons.org/licenses/by/4.0/.

\section{References}

1. Kablov EN. Without new materials - there is no future. Metallurgist. 2014;57:1057-1061. https://doi.org/10.1007/s1101 5-014-9844-z.

2. Rokicki P, Budzik G, Kubiak K, Bernaczek J, Dziubek T, Magniszewski M, Nowotnik A, Sieniawski J, Matysiak H, Cygan R, Trojan A. Rapid prototyping in manufacturing of core models of aircraft engine blades. Aircr Eng Aerosp Technol. 2014;86:323-7. https://doi.org/10.1108/AEAT-10-2012-0192.

3. Rokicki P, Kozik B, Budzik G, Dziubek T, Bernaczek J, Przeszlowski L, Markowska O, Sobolewski B, Rzucidlo A. Manufacturing of aircraft engine transmission gear with SLS (DMLS) method. Aircr Eng Aerosp Technol. 2016;88:397-403. https://doi. org/10.1108/AEAT-05-2015-0137.

4. Aghion E, Bronfin B, Eliezer D. The role of the magnesium industry in protecting the environment. J Mater Process Technol. 
2001;117:381-5. https://doi.org/10.1016/S0924-0136(01)00779 $-8$.

5. Mathes JC. Magnesium alloys in the aircraft industry. Aircr Eng Aerosp Technol. 1941;13:323-6. https://doi.org/10.1108/eb030 844.

6. Perry WH. American experience with magnesium alloys: some details of recent work on aircraft primary structures in magnesium. Aircr Eng Aerosp Technol. 1955;27:416-8. https://doi. org/10.1108/eb032639.

7. Grant LB. Magnesium alloys in the U.S.A.: the development of the production of aircraft parts in this material. Aircr Eng Aerosp Technol. 1940;12:279-82. https://doi.org/10.1108/eb030689.

8. Cieśla M, Junak G, Marek A. Fatigue characteristics of selected light metal alloys. Arch Metall Mater. 2016;61:271-4. https:// doi.org/10.1515/amm-2016-0051.

9. Fleming S. An overview of magnesium based alloys for aerospace and automotive applications. Troy: Rensselaer Polytechnic; 2012.

10. S. Woo Nam, Mg-RE계 고온용 합금의 특성과 최근 연구 동 향 High Temperature Properties and Recent Research Trend of Mg-RE Alloys, Rev. Pap. 대한 금 속.재료 학 회지 (Korean J. Met. Mater.). 55 (2017) 1-9. https://doi.org/10.3365/ kjmm.2017.55.4.

11. Dziadoń A, Mola R. Magnesium-trends of development of mechanical properties. Inżynieria Mater. w Obróbce Plast. 2013;XXIV:253-77.

12. Lu YQ, Zhu XJ, Hu XD, Yao Y, Cai H. Effects of blowing ar on inclusion and properties of AZ61 magnesium alloy. Key Eng Mater. 2017;725:416-20. https://doi.org/10.4028/www.scien tific.net/KEM.725.416.

13. Kuczmaszewski J, Zagórski I, Dziubinska A. Investigation of ignition temperature, time to ignition and chip morphology after the high-speed dry milling of magnesium alloys. Aircr Eng Aerosp Technol. 2016;88:389-96. https://doi.org/10.1108/ AEAT-02-2015-0040.

14. AS8049B: Performance standard for seats in civil rotorcraft, Transport Aircraft, and General Aviation Aircraft, 2005.

15. Davis B. The application of magnesium alloys in aircraft interiors-changing the rules. In: Magnesium technology 2015TMS 2015 144th annual meeting \& exhibition, Orlando, 2015: p. 5.

16. Horner A. DOT/FAA/AR-00/12 Aircraft materials fire test handbook. Virginia: National Technical Information Service (NTIS) Springfield; 2000.

17. Marker TM. DOT/FAA/AR-11/3 Evaluating the flammability of various magnesium alloys during laboratory- and full-scale aircraft fire tests. Virginia: NationalTechnical Information Service (NTIS) Springfield; 2013

18. AS8049C: Performance standard for seats in civil rotorcraft, transport aircraft, and general aviation aircraft, 2015.

19. Tekumalla S, Gupta M. An insight into ignition factors and mechanisms of magnesium based materials: a review. Mater Des. 2017;113:84-98. https://doi.org/10.1016/j.matdes.2016.09.103.

20. Wojtas M, Sobieszek A, Czajkowski Ł, Żurawski R. Modern materials in aerospace industry-fatigue tests of magnesium alloy control system lever of the unmanned Ilx-27. In: 30th Congress of the International Council of the Aeronautical Sciences, Daejeon, Korea, 25-30.09.2016; 2016. pp. 1-7.

21. Dziubinska A, Gontarz A. A new method for producing magnesium alloy twin-rib aircraft brackets. Aircr Eng Aerosp Technol. 2015;87:180-8. https://doi.org/10.1108/AEAT-10-2013-0184.

22. Śliwa RE, Balawender T, Hadasik E, Kuc D, Gontarz A, Korbel A, Bochniak W. Metal forming of lightweight magnesium alloys for aviation applications. Arch Metall Mater. 2017;62:1559-66. https://doi.org/10.1515/amm-2017-0239.
23. Hombergsmeier E. Magnesium for aerospace applications. In: 2nd international conference and exhibition "Magnesium-Broad Horizons"; 2007. p. 1-13.

24. Henn Y, Fein A. Project MagForming-Development of new magnesium forming technologies for the aeronautics industry. Publ Final Act Rep 2010, pp. 16-35.

25. Shim J-D, Byun J-Y. Superplasticity of magnesium alloys and SPF applications. Korean J Mater Res. 2017;21:53-61.

26. Bednarczyk I, Mrugała A, Tomaszewska A. Influence of plastic deformation process on the structure and properties of alloy WE43. Arch Metall Mater. 2016;61:389-92. https://doi. org/10.1515/amm-2016-0071.

27. Avvari M, Able NSM. Microstructure evolution in AZ61 alloy processed by equal channel angular pressing. Adv Mech Eng. 2016;8:168781401665182. https://doi.org/10.1177/1687814016 651820.

28. Gontarz A, Dziubińska A. Forming of flat parts with ribs from magnesium alloy. Aircr Eng Aerosp Technol. 2014;86:356-60. https://doi.org/10.1108/AEAT-10-2012-0188.

29. Mrugała A, Kuc D. Forming construction elements for aviation from light alloys with the use of cold extrusion in complex state of strain. Solid State Phenom. 2016;246:240-3. https://doi. org/10.4028/www.scientific.net/SSP.246.240.

30. Pu Z, Outeiro JC, Batista AC, Dillon OW, Puleo DA, Jawahir IS. Enhanced surface integrity of AZ31B Mg alloy by cryogenic machining towards improved functional performance of machined components. Int J Mach Tools Manuf. 2012;56:17-27. https://doi. org/10.1016/j.ijmachtools.2011.12.006.

31. Taltavull C, Torres B, Lopez AJ, Rodrigo P, Otero E, Rams J. Selective laser surface melting of a magnesium-aluminium alloy. 2012;85:98-101. https://doi.org/10.1016/j.matlet.2012.07.004.

32. Labisz K, Tański T, Kremzer M, Janicki D. Effect of laser alloying on heat-treated light alloys. Int J Mater Res. 2017;108:126-32. https://doi.org/10.3139/146.111456.

33. Chaturvedi V, Sharma A, Pandel U. Effect of mechanical vibrations on grain refinement of AZ91 Mg alloy. Mater Res Express. 2017;2017:1-11.

34. Hao S, Li M, Chen J. Surface microstructure and improved wear resistance of AZ91 magnesium alloy after high current pulsed electron beam treatment. Appl Surf Sci. 2016. https://doi. org/10.1016/j.apsusc.2016.05.137.

35. Çelik İ. Structure and surface properties of $\mathrm{Al}_{2} \mathrm{O}_{3}-\mathrm{TiO}_{2}$ ceramic coated AZ31 magnesium alloy. Ceram Int. 2016;31:3-7. https:// doi.org/10.1016/j.ceramint.2016.05.162.

36. Tan Q, Mo N, Jiang B, Pan F, Atrens A, Zhang MX. Oxidation resistance of $\mathrm{Mg}-9 \mathrm{Al}-1 \mathrm{Zn}$ alloys micro-alloyed with Be. Scr Mater. 2016;115:38-41. https://doi.org/10.1016/j.scriptamat .2015.12.022.

37. Vlček M, Čižek J, Lukáč F, Melikhova O, Hruška P, Procházka I, Vlach M, Stuliková I, Smola B, Jager A. Effects in Mg-Zn-based alloys strengthened by quasicrystalline phase. J Phys Conf Ser. 2016. https://doi.org/10.1088/1742-6596/674/1/012005.

38. Wang F, Ma D, Wang Z, Mao P, Liu Z. Microstructure, mechanical properties and solidification behavior of AM50- $x(\mathrm{Zn}, \mathrm{Y})$ magnesium alloys. Jinshu Xuebao Acta Metall Sin. 2016;52:1115-22. https://doi.org/10.11900/0412.1961.2016.00048.

39. Nia AA, Nourbakhsh SH. Microstructure and mechanical properties of AZ31/SiC and AZ31/CNT composites produced by friction stir processing. Trans Indian Inst Met. 2016;69:1435-42. https:// doi.org/10.1007/s12666-015-0702-x.

40. Qi LH, Wei XL, Zhang T, Liu J, Hou XH, Li HJ. Effect of fabrication parameters on carbon fibre reinforced magnesium matrix composite components. Mater Sci Technol. 2016;0836:1-7. https ://doi.org/10.1179/1743284715Y.0000000147.

41. Aatthisugan I, Rose AR, Jebadurai DS. Mechanical and wear behaviour of AZ91D magnesium matrix hybrid composite 
reinforced with boron carbide and graphite. J Magnes Alloy. 2016;5:20-5. https://doi.org/10.1016/j.jma.2016.12.004.

42. Oddone V, Boerner B, Reich S. Composites of aluminum alloy and magnesium alloy with graphite showing low thermal expansion and high specific thermal conductivity. Sci Technol Adv Mater. 2017;18:1-7. https://doi.org/10.1080/14686996.2017.1286222.

43. Thompson SM, Bian L, Shamsaei N, Yadollahi A. An overview of direct laser deposition for additive manufacturing; part I: transport phenomena, modeling and diagnostics. Addit Manuf. 2015;8:3662. https://doi.org/10.1016/j.addma.2015.07.001.

44. Dordlofva C, Lindwall A, Törlind P. Opportunities and challenges for additive manufacturing in space applications. DS 85-1 Proceedings of NordDesign 2016, Volume 1, Trondheim, Norway, $10^{\text {th }}-12$ th August 2016. (2016). https://www.designsociety.org/ publication/39317/opportunities_and_challenges_for_additive_ manufacturing_in_space_applications. Accessed August 29, 2017.

45. Chlebus E, Gruber K, Kuźnicka B, Kurzac J, Kurzynowski T. Effect of heat treatment on the microstructure and mechanical properties of Inconel 718 processed by selective laser melting. Mater Sci Eng A. 2015;639:647-55. https://doi.org/10.1016/j. msea.2015.05.035.

46. Sames WJ, List FA, Pannala S, Dehoff RR, Babu SS. The metallurgy and processing science of metal additive manufacturing. Int Mater Rev. 2016. https://doi.org/10.1080/09506 608.2015.1116649.

47. Kurzynowski T, Chlebus E, Kuźnicka B, Reiner J. Parameters in selective laser melting for processing metallic powders. In: Beyer E, Morris T, editors. Proceedings of SPIE 8239 High Power Laser Materials Processing: Lasers, Beam Delivery. Diagnostics, 2012. https://doi.org/10.1117/12.907292.

48. Bai S, Yang L, Liu J. Manipulation of microstructure in laser additive manufacturing. Appl Phys A. 2016;122:495. https:// doi.org/10.1007/s00339-016-0023-x.

49. Chlebus E, Kuznicka B, Kurzynowski T, Dybala B. Microstructure and mechanical behaviour of Ti-6Al-7Nb alloy produced by selective laser melting. Mater Charact. 2011;62:488-95. https ://doi.org/10.1016/j.matchar.2011.03.006.

50. Rashid R, Masood SH, Ruan D, Palanisamy S, Rahman Rashid RA, Elambasseril J, Brandt M. Effect of energy per layer on the anisotropy of selective laser melted AlSi12 aluminium alloy. Addit Manuf. 2018;22:426-39. https://doi.org/10.1016/j.addma .2018.05.040.

51. Yap CY, Chua CK, Dong ZL, Liu ZH, Zhang DQ, Loh LE, Sing SL. Review of selective laser melting: materials and applications. Appl Phys Rev. 2015;2:041101. https://doi. org/10.1063/1.4935926.

52. Ziółkowski G, Chlebus E, Szymczyk P, Kurzac J. Application of X-ray CT method for discontinuity and porosity detection in $316 \mathrm{~L}$ stainless steel parts produced with SLM technology. Arch Civ Mech Eng. 2014;14:608-14. https://doi.org/10.1016/j. acme.2014.02.003.

53. Poprawe R, Hinke C, Meiners W, Schrage J, Bremen S, Risse J, Merkt S. Disruptive innovation through 3D printing. In: Supply chain integration challenges in commercial aerospace, Cham: Springer; 2017. p. 73-87. https://doi.org/10.1007/978-3-31946155-7_6.

54. Fera M, Fruggiero F, Lambiase A, Macchiaroli R. State of the art of additive manufacturing: review for tolerances, mechanical resistance and production costs. Cogent Eng. 2016. https://doi. org/10.1080/23311916.2016.1261503.

55. Baufeld B, Brandl E, van der Biest O. Wire based additive layer manufacturing: comparison of microstructure and mechanical properties of Ti-6 Al-4V components fabricated by laser-beam deposition and shaped metal deposition. J Mater Process Technol. 2011;211:1146-58. https://doi.org/10.1016/j.jmatprotec .2011.01.018
56. Chlebus E, Kuznicka B, Dziedzic R, Kurzynowski T. Titanium alloyed with rhenium by selective laser melting. Mater Sci Eng A. 2014;620:155-63. https://doi.org/10.1016/j. msea.2014.10.021.

57. Pawlak A, Szymczyk P, Ziolkowski G, Chlebus E, Dybala B. Fabrication of microscaffolds from Ti-6Al-7Nb alloy by SLM. Rapid Prototyp J. 2015;21:393-401. https://doi.org/10.1108/ RPJ-10-2013-0101.

58. Rockstroh T, Abbott D, Hix K, Mook J. Additive manufacturing at GE aviation-industrial laser solutions, (2013). http://www. industrial-lasers.com/articles/print/volume-28/issue-6/features/ additive-manufacturing-at-ge-aviation.html. Accessed June 1, 2017.

59. Bamberg J, Zenzinger G, Ladewig A. In-process control of selective laser melting by quantitativa optical tomography. In: 19th World Conference on Non Destructive Testing 2016, NDT.net, Munich, 2016. http://www.ndt.net/article/wcndt2016/papers/th1b1 .pdf. Accessed 16 Jan 2019.

60. Brandt M, Sun SJ, Leary M, Feih S, Elambasseril J, Liu QC. Highvalue SLM aerospace components: from design to manufacture. Adv Mater Res. 2013;633:135-47. https://doi.org/10.4028/www. scientific.net/AMR.633.135.

61. Seabra M, Azevedo J, Araújo A, Reis L, Pinto E, Alves N, Santos R, Mortágua JP. Selective laser melting (SLM) and topology optimization for lighter aerospace componentes. Procedia Struct Integr. 2016;1:289-96. https://doi.org/10.1016/j.prost r.2016.02.039.

62. Rashid R, Masooda SH, Ruan D, Palanisamy S, Huang X, Rashid RAR. Topology optimisation of additively manufactured lattice beams for three-point bending test. In: Solid freeform fabrication 2018: Proceedings of the 29th annual international solid freeform fabrication symposium - an additive manufacturing conference, Austin, Texas, pp. 635-645.

63. Kellner T. World's first plant to print jet engine nozzles in mass production, 2014. http://www.ge.com/reports/post/9176381509 5/worlds-first-plant-toprint-jet-engine-nozzles-in/. Accessed 30 Aug 2017.

64. Nimbalkar S, Cox D, Visconti K, Cresko J. Life cycle energy assessment methodology, tool and case studies for additive manufacturing, 2014. http://ammo.ncms.org/documents/Resources/ ProjectCalls/LifeCycleEnergyAssessmentMethodology\%2CToo $1 \% 2$ CandCaseStudiesforAdditiveManufacturing.pdf. Accessed August 30, 2017.

65. Joshi SC, Sheikh AA. 3D printing in aerospace and its long-term sustainability. Virtual Phys Prototyp. 2015;10:175-85. https://doi. org/10.1080/17452759.2015.1111519.

66. Additive manufacturing. A game changer for the manufacturing industry? (2013). https://www.rolandberger.com/en/Publications/ pub_additive_manufacturing_2013.html. Accessed August 30, 2017.

67. U.S. Department of Energy, Chapter 6: Innovating clean energy technologies in advanced manufacturing I additive manufacturing technology assessment, 2015. https://energy.gov/sites/prod/files /2015/11/f27/QTR2015-6A-AdditiveManufacturing.pdf. Accessed August 30, 2017.

68. Schiller GJ. Additive manufacturing for aerospace. In: 2015 IEEE Aerospace Conference. IEEE 2015. p. 1-8. https://doi. org/10.1109/AERO.2015.7118958.

69. Aumund-Kopp C, Riou A. Introduction to additive manufacturing technology. A guide for designers and engineers, (2015) 43. www. epma.com. Accessed August 31, 2017.

70. Rawal S, Brantley J, Karabudak N. Additive manufacturing of Ti-6Al-4V alloy components for spacecraft applications. In: 2013 6th International conference on recent advances in space technologies. IEEE, 2013. p. 5-11. https://doi.org/10.1109/ RAST.2013.6581260. 
71. Shapiro AA, Borgonia JP, Chen QN, Dillon RP, McEnerney B, Polit-Casillas R, Soloway L. Additive manufacturing for aerospace flight applications. J Spacecr Rockets. 2016;53:952-9. https ://doi.org/10.2514/1.A33544.

72. Uriondo A, Esperon-Miguez M, Perinpanayagam S. The present and future of additive manufacturing in the aerospace sector: a review of important aspects. Proc Inst Mech Eng Part G J Aerosp Eng. 2015;229:2132-47. https://doi.org/10.1177/0954410014 568797.

73. Zhang B, Liao H, Coddet C. Effects of processing parameters on properties of selective laser melting $\mathrm{Mg}-9 \% \mathrm{Al}$ powder mixture. Mater Des. 2012;34:753-8. https://doi.org/10.1016/j.matde s.2011.06.061.

74. Jauer L, Meiners W, Poprawe R. Selective laser melting of biodegradable metals. Eur Cells Mater. 2013;26:21.

75. Gieseke M, Nölke C, Kaierle S, Maier HJ, Haferkamp H. Selective laser melting of magnesium alloys for manufacturing individual implants. In: Fraunhofer Direct Digital Manufacturing Conference 2014, 2014. p. 1-6.

76. Matena J, Petersen S, Gieseke M, Teske M, Beyerbach M, Kampmann A, Escobar H, Gellrich N-C, Haferkamp H, Nolte I. Comparison of selective laser melted titanium and magnesium implants coated with PCL. Int J Mol Sci. 2015;16:13287-301. https://doi.org/10.3390/ijms160613287.

77. Jauer L, Jülich B, Voshage M, Meiners W. Selective laser melting of magnesium alloys. Eur Cell Mater. 2015;vol 30(Suppl 3).

78. Gieseke M, Tandon R, Kiesow T, Wessarges Y. Selective laser melting of elektron ${ }^{\circledR}$ MAP 43 magnesium powder matthias. In: Rapid technology - international trade show \& conference for Additive Manufacturing. Proc. 13th Rapid.Tech Conf. 14-16 June 2016, Erfurt, 2016: p. 244-252.

79. Tandon R, Wilks T, Gieseke M, Noelke C, Kaierle S, Palmer T. Additive manufacturing of elektron ${ }^{\circledR} 43$ alloy using laser powder bed and directed energy deposition. In: Euro PM2015, 2015.

80. Tandon R, Palmer T, Gieseke M, Noelke C, Kaierle S. Additive manufacturing of magnesium alloy powders: investigations into process development using elektron ${ }^{\circledR} \mathrm{MAP}+43$ via laser powder bed fusion and directed energy deposition. In: Euro PM2016, Reims, 2016. p. 4-9.

81. Manakari V, Parande G, Gupta M, Lopez HF. Selective laser melting of magnesium and magnesium alloy powders: a review. Metals. 2017. https://doi.org/10.3390/met7010002.

82. Hu D, Wang Y, Zhang D, Hao L, Jiang J, Li Z, Chen Y. Experimental investigation on selective laser melting of bulk netshape pure magnesium. Mater Manuf Process. 2015. https://doi. org/10.1080/10426914.2015.1025963.

83. Pawlak A, Chlebus E. Process parameter optimization of laser micrometallurgy of aZ31 alloy. Interdiscip J Eng Sci. 2015;3:10-5.

84. Pawlak A, Rosienkiewicz M, Chlebus E. Design of experiments approach in AZ31 powder selective laser melting process optimization. Arch Civ Mech Eng. 2017;17:9-18. https://doi. org/10.1016/j.acme.2016.07.007.

85. Pawlak A, Szymczyk P, Kurzynowski T, Chlebus E. Selective laser melting of magnesium AZ31B alloy powder. Rapid Prototyp J. 2019. https://doi.org/10.1108/rpj-05-2019-0137.

86. Salehi M, Maleksaeedi S, Farnoush H, Nai MLS, Meenashisundaram GK, Gupta M. An investigation into interaction between magnesium powder and Ar gas: implications for selective laser melting of magnesium. Powder Technol. 2018;333:252-61. https ://doi.org/10.1016/j.powtec.2018.04.026.

87. Wei $\mathrm{K}$, Wang Z, Zeng X. Influence of element vaporization on formability, composition, microstructure, and mechanical performance of the selective laser melted $\mathrm{Mg}-\mathrm{Zn}-\mathrm{Zr}$ components. Mater Lett. 2015;156:187-90. https://doi.org/10.1016/j.matle t.2015.05.074.

88. Shuai C, Yang Y, Wu P, Lin X, Liu Y, Zhou Y, Feng P, Liu X, Peng S. Laser rapid solidification improves corrosion behavior of Mg-Zn-Zr alloy. J Alloys Compd. 2017;691:961-9. https://doi. org/10.1016/j.jallcom.2016.09.019.

89. Proaño B, Miyahara H, Matsumoto T, Hamada S, Sakai H, Ogawa K, Suyalatu, Noguchi H. Weakest region analysis of non-combustible $\mathrm{Mg}$ products fabricated by selective laser melting. Theor Appl Fract Mech. 2019;103:102291. https://doi.org/10.1016/j. tafmec.2019.102291.

90. Li Y, Jahr H, Zhang XY, Leeflang MA, Li W, Pouran B, Tichelaar FD, Weinans H, Zhou J, Zadpoor AA. Biodegradation-affected fatigue behavior of additively manufactured porous magnesium. Addit Manuf. 2019;28:299-311. https://doi.org/10.1016/j.addma .2019.05.013.

91. Savalani MM, Pizarro JM. Effect of preheat and layer thickness on selective laser melting (SLM) of magnesium. Rapid Prototyp J. 2016;22:115-22. https://doi.org/10.1108/RPJ-07-2013-0076.

92. Ng CC, Savalani MM, Lau ML, Man HC. Microstructure and mechanical properties of selective laser melted magnesium. Appl Surf Sci. 2011;257:7447-54. https://doi.org/10.1016/j.apsus c.2011.03.004.

93. Ng CC, Savalani MM, Man HC. Fabrication of magnesium using selective laser melting technique. Rapid Prototyp J. 2011;17:479_ 90. https://doi.org/10.1108/13552541111184206.

94. Chlebus E, Pawlak A, Kurzynowski T, Dybała B. Raporty Wydziału Mechanicznego Politechniki Wrocławskiej. Instruction for working with powder materials. Ser. SPR nr 192, 2016.

95. Liu S, Yang W, Shi X, Li B, Duan S, Guo H, Guo J. Influence of laser process parameters on the densification, microstructure, and mechanical properties of a selective laser melted AZ61 magnesium alloy. J Alloys Compd. 2019;808:151160. https://doi. org/10.1016/j.jallcom.2019.06.261.

96. Wei K, Gao M, Wang Z, Zeng X. Effect of energy input on formability, microstructure and mechanical properties of selective laser melted AZ91D magnesium alloy. Mater Sci Eng A. 2014;611:212-22. https://doi.org/10.1016/j.msea.2014.05.092.

97. Mirovsky Y, Bendov A, Leibovich H, Gurman A, Yurovich Y, Diskin Y, Steckelman Y, Ramati S, Idel S, Kalman Y, Gerhard M, Rubinstein D. Clean sky: the future of the aviation industrydevelopments at israel aerospace industries. In: 54th israel annual conference on aerospace sciences 2014, technion israel institute of technology, Tel-Aviv, 2014. p. 1715-1723.

Publisher's Note Springer Nature remains neutral with regard to jurisdictional claims in published maps and institutional affiliations. 